\title{
New Data on the Upper Miocene Presence in the Aegean Region: The Geological Evolution of Spetses Island, Peloponnesus, Greece
}

\author{
Evdoxia E. Lykoudi \\ Department of Geological Sciences, School of Mining Engineering and Metallurgy, \\ National Technical University of Athens, Athens, Greece \\ Email: elykoudi@metal.ntua.gr
}

Received 27 January 2014; revised 23 February 2014; accepted 2 March 2014

Copyright (C) 2014 by author and Scientific Research Publishing Inc.

This work is licensed under the Creative Commons Attribution International License (CC BY). http://creativecommons.org/licenses/by/4.0/

(c) (i) Open Access

\begin{abstract}
Based on detailed geological and geomorphological mapping, sampling and micro-palaeontological determinations, both of the alpine and neogene formations, new data have been derived for Spetses Island (SW Aegean). The applied methodology provided results on the paleogeographic evolution for Spetses Island and the nearby land of Argolida peninsula as well. Based mainly on characteristic nannofossils, a Miocene age of the post-alpine formations is determined. It is the first time that miocene formations have been identified, not only in Spetses Island and Argolida, but in the whole area of Peloponnesus, where only Plio-pleistocene deposits have been described. This work also leads to the conclusion that Spetses Island is attached to the Argolida peninsula, forming an independent paleogeographic unit since Upper Miocene.
\end{abstract}

\section{Keywords}

Upper Miocene; Microfauna; Spetses Island; Aegean Region

\section{Introduction}

The island of Spetses is located near the south-western coast of the Argolida peninsula, in central Peloponnesus (Figure 1). Until today, the geological structure and the paleogeographic evolution of the island are unknown to a large extent. Some information was provided by the geological map of Greece in scale 1:500,000, where the Neogene formations were referred to as of plio-pleistocene age [1], while other authors also reported the presence of plio-pleistocene sediments on the island of Spetses [2] [3]. This geological, geomorphological and stratigraphical work resulted in the compilation of the geological map of the island and the identification of the factors that 


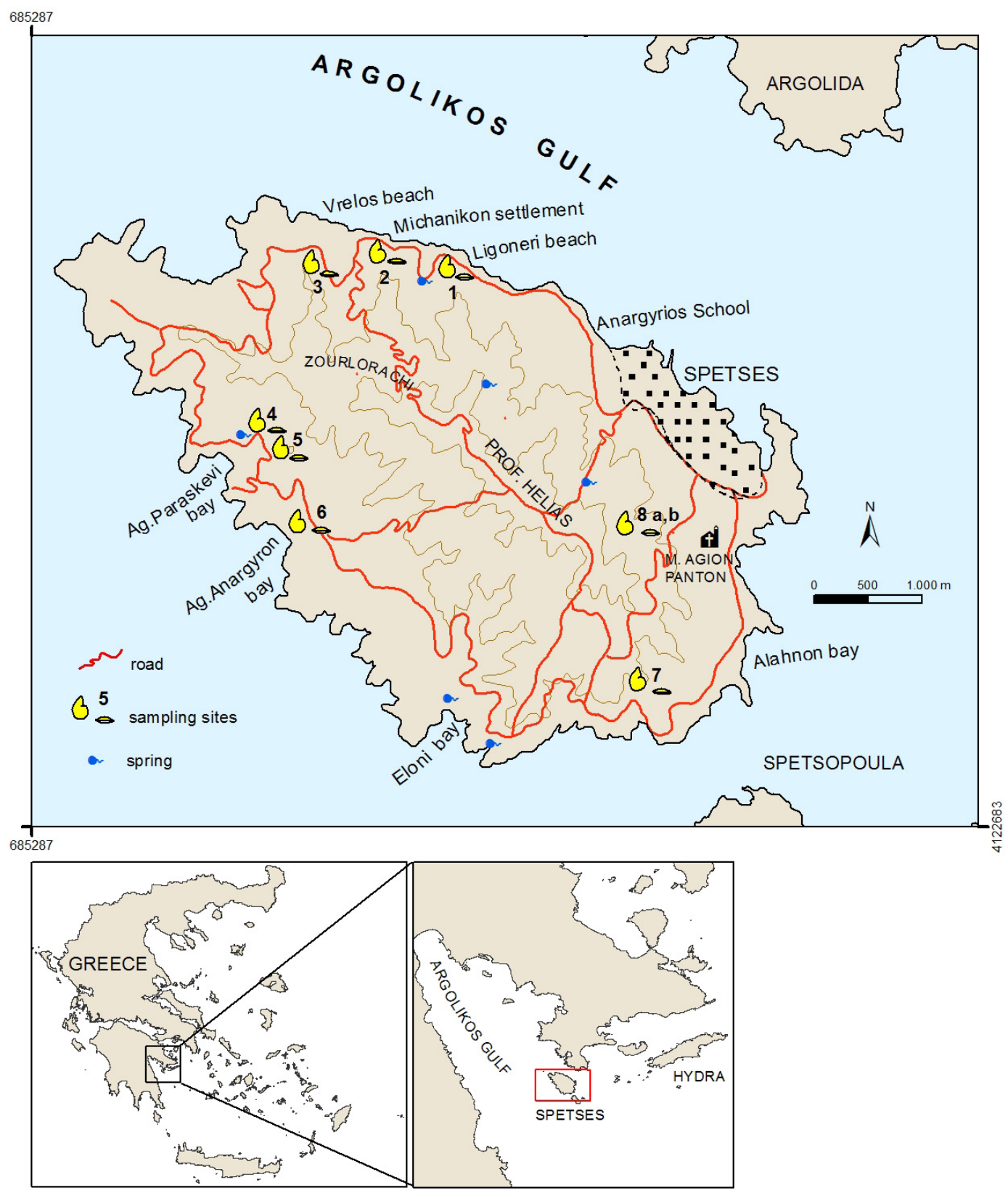

Figure 1. Topographic map of Spetses Island with the sampling sites. Inset map the Argolikos gulf and Argolida peninsula.

shaped the Spetses canal. Moreover, the determination of Upper Miocene sediments contributed to obtaining a better view for the paleogeographic evolution for this part of the Aegean region.

The plio-pleistocene sediments located in the northern part of the Argolikos gulf and further north at the Corinthiakos Gulf, were deposited, during Pliocene, in a large sedimentation basin after a tectonic depression process which connected the Argolikos and Corinthiakos Gulfs. Through this process, the Argolida region and Spetses Island developed as individual blocks, separated by a wide canal [4].

\section{Stratigraphy}

The geological mapping of the island was carried out on topographic maps in a scale 1:25,000 and was initiated by the use of air-photographs, obtained from the Greek Army Geographic Survey, in scale 1:33,000. My atten- 
tion was focused on the neogene sediments, which cover almost the whole island. These sediments are underlain by the so called "Pantokrator” limestones of Upper Triassic-Lower Jurassic age (Figures 2 and 3).

\subsection{Mesozoic Limestones}

The limestones at the "Pantokrator" facies crop out at the southern part of the island, near Eloni bay (Figures 2 and 3). They are massive or thick-bedded and highly fractured. Their colour ranges from dark to light grey while in certain places beige colours dominate. In various locations brecciation phenomena appear along the faults zones. Due to intense recrystallization, the numerous big fossils observed within the limestone mass could not be determined. Therefore, such kind of fossils indicates a shallow marine deposition environment. Moreover, the presence of Foraminifera, Gastropods, Corals, Algae (Dasycladaceae) and Lamellibrachia, indicate reef-related deposition processes.

Analogous limestone formations appear on the Argolida peninsula and the neighbouring Island of Hydra [5]. These formations correspond to the neritic sequence of the "Pantokrator" facies, at the southern edge of the Tethys, which exhibits all the characteristics of a sinking carbonate platform, affected by the tensional tectonism that dominated during the opening of the Tethys Sea [6]. For this reason, the age of these formations in the study area is considered similar to the analogous formations of the Argolida peninsula and Hydra Island. The limited number of fossils that were found could justify this consideration.

\subsection{Neogene Sediments}

Although the neogene formations present often vertical and horizontal alternations, two main litho-stratigraphic units were identified. The lower litho-stratigraphic unit, consisted of unconsolidated fine material and the upper unit, composed by cohesive and coarse sediments (Figures 2 and 3).

The lower litho-stratigraphic unit, extended in the area of Ligonerio, is composed mainly of limestone marls with thin marly limestone intercalations, while rare limestone concretions are enclosed within the marls. These layers are covered by conglomerates, composed of elements ranging from 2 to $12 \mathrm{~cm}$ in diameter. They consist mainly of cretaceous limestone cobbles and less frequency of radiolarian limestones, sandstones from flysch and rounded fragments of basic or ultra-basic rocks. They are cemented with sandstone or marly sandstone material. Within the conglomerates, locally thin sandstone layers (30 - $50 \mathrm{~cm}$ in thickness) are intercalated. The uppermost part of this sequence consists of finer and more compact material.

The upper litho-stratigraphic unit is composed almost exclusively by thick cohesive conglomerates on which thin horizons of marly and microbrecciated sandstones have been deposited. The top layers are represented by conglomerates consisting of small sized cobbles and gravels, which in some places reach in size up to $25 \mathrm{~cm}$.

The microfauna of Foraminifera and the nanno-fossils which could be identified (Table 1), indicate an Upper Miocene age and the following deposition conditions: a) the sediments were deposited in a coastal marine en-

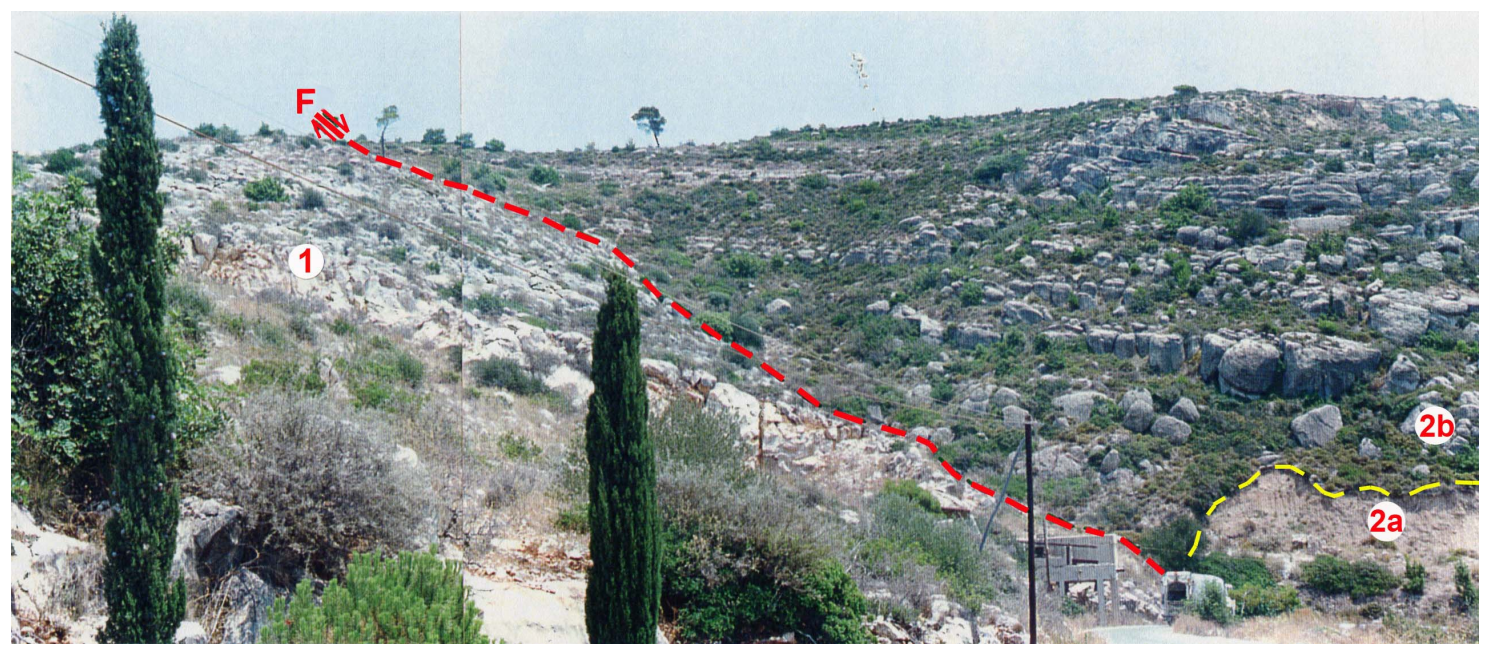

Figure 2. Fault (F) of Eloni. 1. Mesozoic limestones, 2. Neogene sediments, clayey marls (2a), conglomerates (2b). 

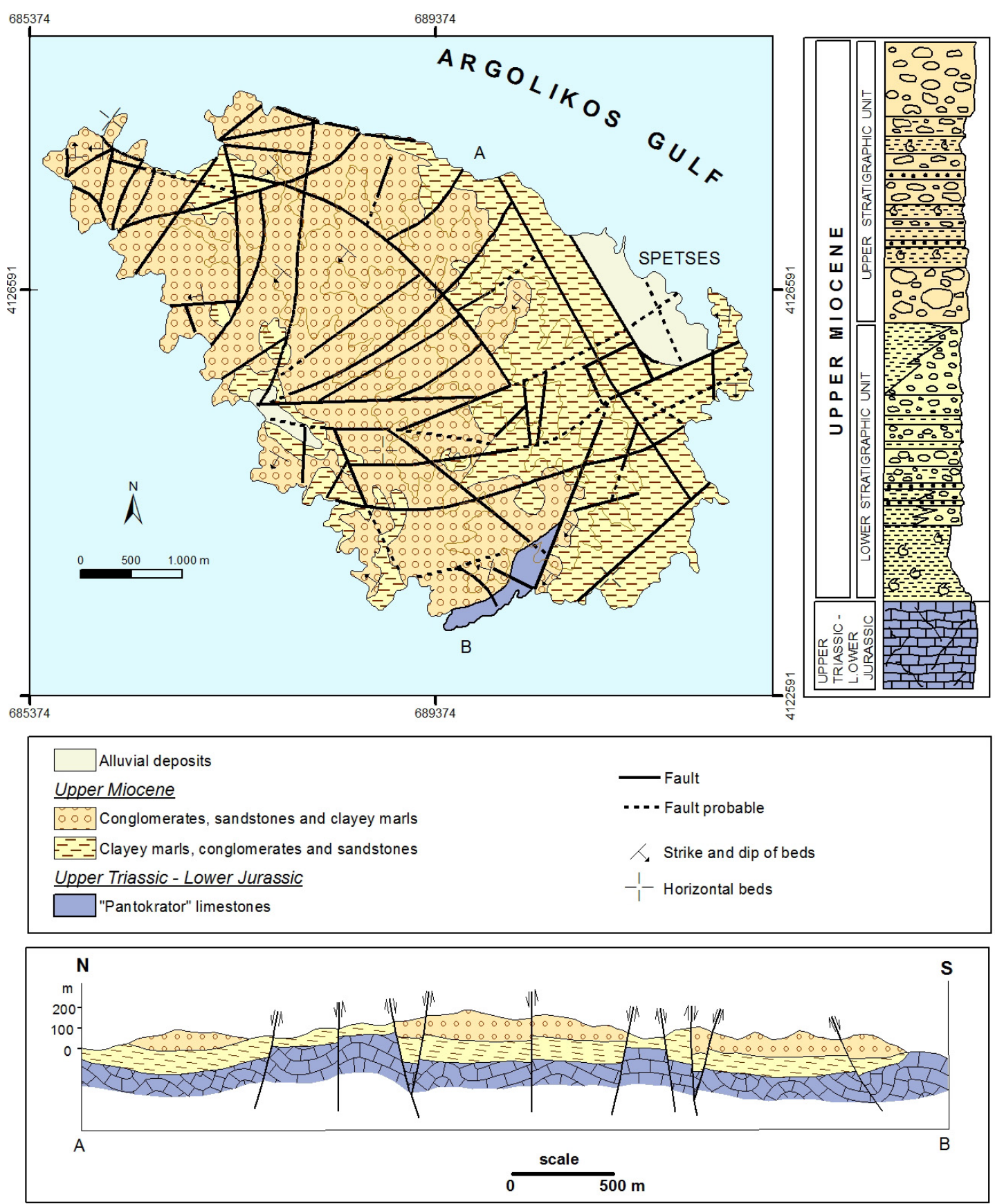

Figure 3. Geological map of Spetses island, schematic stratigraphic column and geological cross-section (A)-(B).

vironment with normal salinity which was occasionally connected to the open sea; b) the climate was tropical or sub-tropical; c) the marine waters exhibited high temperature and (d) the sedimentation took place at depths down to $30 \mathrm{~m}$. Moreover, other identified nanno-fossils, such as Reticulofenestra umbilica, Watznaueria barnesae, Coccolithus abisectus, Sphenolithus moriformis, indicate re-sedimentation processes.

\subsection{Quaternary Deposits}

The quaternary deposits, both of continental and marine origin, present a variety in lithology.

River and torrent deposits: They outcrop at the west beach of the city of Spetses, the beach of the Michanikon settlement, the Alahnon bay etc. They are loose formations composed of sands with limestone fragments. 
Table 1. Distribution of the microfauna identified on the island of Spetses.

\begin{tabular}{|c|c|c|c|c|c|c|c|c|c|c|}
\hline & \multirow{2}{*}{ MICROFAUNA } & \multicolumn{9}{|c|}{ SAMLES } \\
\hline & & 1 & 2 & 3 & 4 & 5 & 6 & 7 & $8 a$ & $8 b$ \\
\hline \multirow{29}{*}{ 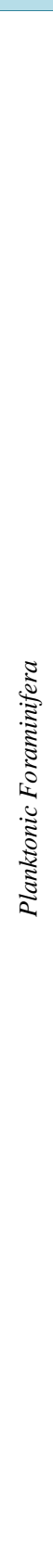 } & ${ }^{*}$ Globorotalia acostaensis BLOW & * & & * & & * & * & $*$ & & \\
\hline & ${ }^{*}$ Globorotalia aff. scitula subsctula CONATO & & & & & * & & & & \\
\hline & ${ }^{*}$ Globorotalia gr. humerosa-dutetrei & & & * & & & & * & & \\
\hline & ${ }^{* *}$ Globorotalia humerosa-humerosa (TAKAYANAGI \& SAITO) & & & & & & & & * & \\
\hline & *Globorotalia gr. menardii (PARKER, JONES \& BRADY) & * & & * & & & & * & & \\
\hline & ${ }^{*}$ Globorotalia continuosa (BLOW) & * & & * & * & $*$ & * & & & * \\
\hline & Globorotalia scitula (BRADY) & & & & & & & * & & \\
\hline & ${ }^{*}$ Globorotalia merotumida (BLOW \& BANNER) & & & & * & & & & & \\
\hline & Globorotalia sp. & & & & & & * & & & \\
\hline & Globorotalia mediterranea (CATALANO \& SPROVIERI) & & & & & & & & * & \\
\hline & Globorotalia obesa (BOLLI) & & & & $*$ & & & & & $*$ \\
\hline & *Globorotalia pseudomiocenica (BOLLI \& BERMUDEZ) & & & & $*$ & & & & & \\
\hline & Globigerina apertura (CUSHMAN) & & & & & & & * & & \\
\hline & Globigerina decoraperta (TAKAYANAGI \& SAITO) & & & & & & & * & * & \\
\hline & Globigerina bulloides (BULLOIDES D’ ORBIGNY) & & & & & * & & * & & \\
\hline & Globigerina falconensis (BLOW) & & & & & & & * & & \\
\hline & Globigerina nepenthes (TODD) & & & & * & & & & * & $*$ \\
\hline & "Globigerina nepenthes (TAKAYANAGI \& SAITO) & * & & & & & & & & \\
\hline & ${ }^{*}$ Globigerinoides bollii BLOW & & & & & * & & & & \\
\hline & Globigerinoides bollii BOLLI \&BLOW & * & & & & & * & & & \\
\hline & Globigerinoides obliquus BOLLI & & & & & $*$ & & * & & \\
\hline & Globigerinoides obliquus extremus BOLLI \& BERMUDEZ & & & & & * & & * & & \\
\hline & Globigerinoides trilobus (REUSS) & & & & & * & & * & & \\
\hline & Globoquadrina gr. altispira CUSHMAN \& JARVIS & & & & * & & & & & \\
\hline & Globoquadrina gr. & & & & & & & & & * \\
\hline & ${ }^{* *}$ Neogloboquadrina dutertrei (D'ORBIGNY) & & & & & & & & $*$ & \\
\hline & Orbulina universa D’ ORBIGNY & * & & & $*$ & * & * & $*$ & * & \\
\hline & Orbulina suturalis BRONNIMANN & & & * & * & * & & & & \\
\hline & Orbulina sp. & & & & & & & & & * \\
\hline \multirow{6}{*}{ 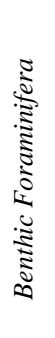 } & Ammonia gr. beccarii (LINE) & & $*$ & & & & & & * & \\
\hline & Anomalinoides sp. & & * & * & & & & & & \\
\hline & Asterigerinata planorbis (D’ ORBIGNY) & & & & * & & & & & $*$ \\
\hline & Bulimina alazanensis (CUSHMAN) & $*$ & & & & & & & & \\
\hline & Bulimina costata (D’ ORBIGNY) \& SEGUENZA) & * & & * & * & & * & & & \\
\hline & Bulimina echinata (D’ ORBIGNY) & * & & & & & & & & \\
\hline
\end{tabular}




\section{Continued}

Brizalina dilatata (REUSS)

Brizalina sp.

*Bolivina miocenica (GIANOTTI)

Elphidium advenum (CUSHMAN)

Elphidium crispum (LINNE)

Elphidium macellum (FICHTEL \& MOOL)

Florilus boueanum (D’ ORBIGNY)

Gyroidina soldanii (D’ ORBIGNY)

Gyroidinoides sp.

Heterolepa floridana (CUSHMAN)

Heterolepa $s p$.

Lagena sp.

Lenticulina calcar (LINNE)

Lenticulina gibba (D’ ORBIGNY)

Lenticulina rotulata (LAMARCK)

Melonis sp.

Planulina $s p$.

Planulina ariminensis D’ ORBIGNY

Planulina wullerstorfi (SCHWAGER)

Siphonina planoconvexa (SILVESTRI)

Siphonina reticulata (CZEZEK)

Sigmoilina celata (COSTA)

Textularia sagittula (TEDESCHI \& ZANMATTI)

Uvigerina auberiana (D’ ORBIGNY)

Uvigerina longistriata (PERCONIG)

Uvigerina peregrina CUSHMAN

Uvigerina cf proboscidea SCHWAGER

Uvigerina rutila (CUSHMAN \& TODD)

Uvigerina sp.

Radiolaria

Echinoidea spicule

Porifera spicule

Ostracoda

Fragments Ostracods

\section{Amaurolithus delicatus}

*Amaurolithus tricorniculatus NN12

Ceratolithus acutus 


\title{
Continued
}

\author{
${ }^{*}$ Ceratolithus primus NN11b \\ Ceratolithus sp. \\ Cyclococcolithium leptopora \\ Cyclococcolithus formosus \\ Cyclococcolithus sp. \\ Coccolithus abisectus \\ Coccolithus pelagicus
}

Coccolithus sp.

Reticulofenestra umbilica

Discoaster aulakos

*Discoaster berggrenii NN11

${ }^{*}$ Discoaster berggrenii NN11a

Discoaster berggrenii

* Discoaster brouweri NN112

Discoaster brouweri

Discoaster hamatus

Discoaster cf. calcaris

Discoaster calcaris

Discoaster loeblichii

Discoaster neohamatus NN10

"Discoaster pentaradiatus NN112

Discoaster pentaradiatus

Discoaster surculus

Discoaster sp.

${ }^{*}$ Discoaster quinqueramus NN11

${ }^{*}$ Discoaster quinqueramus NN11b

Discoaster quinqueramus

Helicosphaera kamptneri

Helicosphaera sp.

Reticulofenestra umbilica

Sphenalithus moriformis

Watznaueria barnesae

${ }^{*}$ Characteristic microfossils aged Upper Miocene (Tortonian); ${ }^{* *}$ Characteristic microfossils aged Upper Miocene (Messinian).

Alluvial deposits: These formations dominate at the city of Spetses and at a part of the Agion Anargyron bay. They show a small thickness and are composed of clayey-sandy material and gravels.

Beachrock formations: They are cohesive sandstone rocks of recent geological age. They are composed of material of various sizes (sands, gravels) while the cement is mainly calcitic. They have been formed along the 
mean tidal belt and their thickness depends on the tidal range in the area. At the northern and northeastern part of Spetses Island, beachrocks can be found at the western part of the city of Spetses. They appear along the coastline, both above and below the sea level and at the beach in front of Anargyrio School. In parallel to the coastline, three different underwater beachrock series appear at a depth between a few centimeters and $3 \mathrm{~m}$. Inside this beachrock formation numerous molluscs are intercalated.

To determine the geological evolution of Spetses Island, a systematic micropalaeontological study, with numerous probes from 16 sample-sites was carried out (Figure 1, Table 1). The study of the macro-, micro- and nanno-fauna, collected from the whole number of samples, revealed information concerning several environmental parameters i.e. depth, salinity, temperature, etc. A significant number of the benthic foraminifera (Ammonia beccarii, Elphidium sp.) are epiphytic and thus, connected with the euphoric zone. They indicate a coastal environment characterised by high water temperature and shallow depths.

\section{Paleogeographic Evolution}

Based on the above geological and geomorphological data, the paleogeographic evolution of the broader Spetses Island was reconstructed (Figure 4). The Aegean Sea is actually a marginal sea. Its formation initiated during Middle Miocene and continues until today. The tensional tectonism started during Upper Miocene affecting the continental lithosphere, which had been thickened during previous alpine compression. This tensional tectonism is responsible for the formation of the Aegean Sea and the neogene basins as well. The vertical displacements along the new faults and the reactivated old ones have resulted in the appearance of horsts and graben structures. Those faults, which are responsible for the creation of the islands and the depressions in the Aegean Sea, are of normal type and their movement is complicated (part rotation or multiple parts rotation) which finally result to the extension of the in between area. According to other researchers [7] [8], except of the normal faults, some strike-slip faults exist which have been formed during Upper Miocene-Lower Pliocene. Due to the reactivation of the NW-SE and ENE-WSW directed faults, the Argolikos gulf and the Argolida peninsula have been shaped.

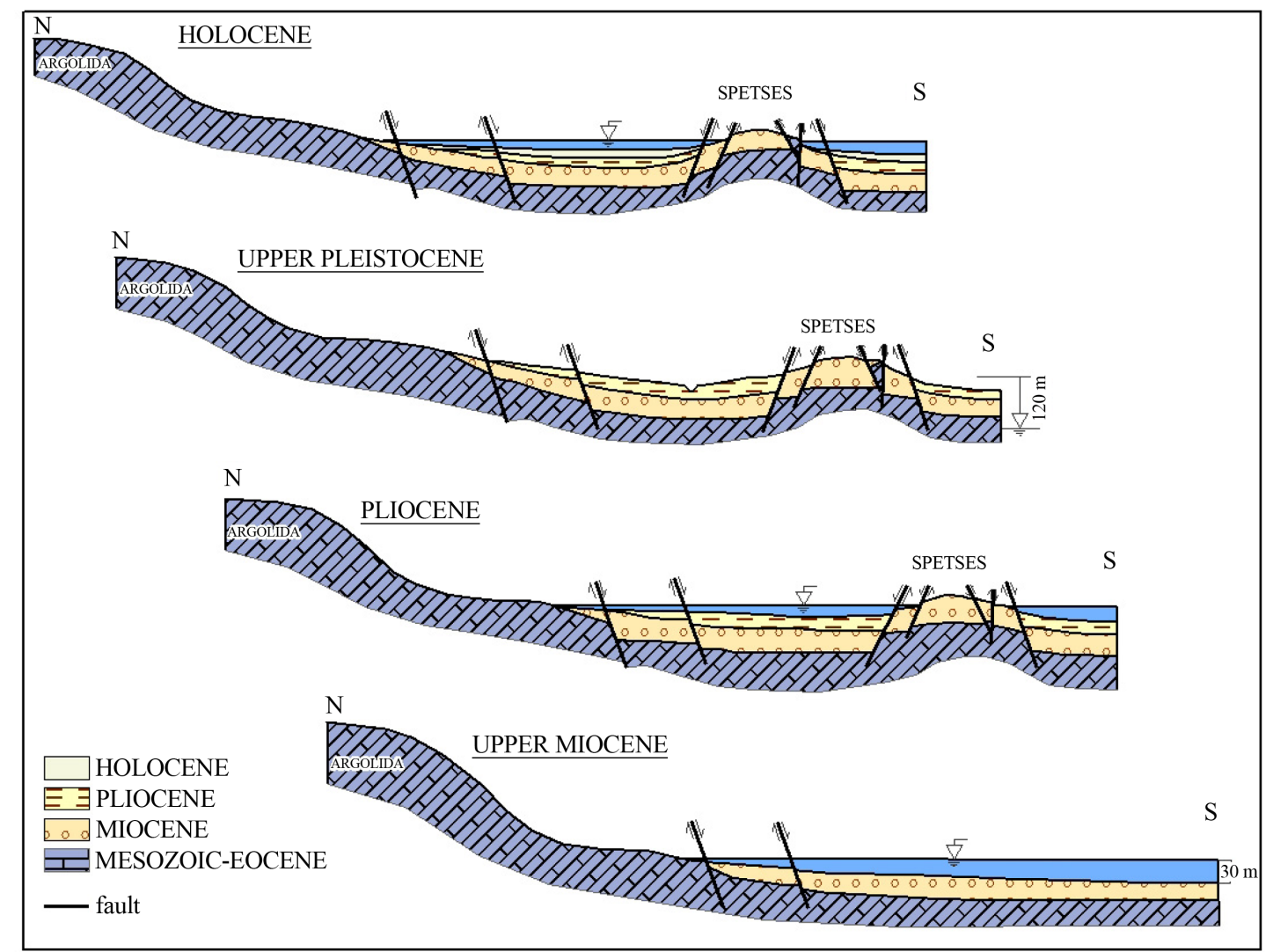

Figure 4. Schematic representation of the paleogeographic evolution of Spetses island. 
Moreover, between south Argolida and Spetses Island a similar smaller tectonic depression had been formed. Some of those faults may be still active. As a result of the above mentioned movements, those faults appear gradually displaced towards the northeast and southwest of the Spetses island, while the island rotates round an axis parallel to the faults that have a NW-SE direction. This rotation resulted in an inclination of the layers towards the southwest and a rise of the north-eastern part of the island.

During the Upper Miocene, the study area was actually a coastal marine environment with a depth of $30 \mathrm{~m}$ and a tropical-subtropical climate, according to the studied micro-, macro- and nanno-fauna. In addition, from the evidence of the continuous successions of conglomerates, sandstones and marls, this environment was occasionally connected to the open sea.

The Upper Miocene and Lower Pliocene sediments of Spetses Island originate from the adjacent areas; either from the Olonos-Pindos geotectonic zone that structures the East Peloponnesus or the "Native and Upper Unity" (B, C Unities) of the Argolida peninsula [9]. The first case (the material to be originated from the East Peloponnesus), however, is rather impossible. The limestone elements of Upper Cretaceous age could originate from the limestones of Olonos-Pindos zone but the appearance of sandstone and volcanic fragments support another explanation. Sourcerocks with such a spectra (flysch and volcanic rocks) do not exist in the area of East Peloponnesus. The study area received materials during the Upper Miocene from the adjacent Argolida region after the depositions of the ophiolitic units. The transgressive upper cretaceous limestones and flysch formations were deposited on the carbonate platform of the "Pantokrator" facies (native unity), giving the sedimentation material which deposited in Spetses Island. The supply of the study area with materials from the Argolida peninsula indicates that during Upper Miocene the area of the Argolida peninsula were uplifted, due to intense tectonic activity, and provided the southern areas with such materials.

It is not certain whether the sedimentation has continued during the Pliocene in the study area. Pliocene sediments, according to the results of the micropaleontological study, have not yet been found on the island. In addition to this observation, the thickness of the upper Miocene sediments is not as high as expected, although it is known that sediments deposited in coastal areas usually exhibit high thickness.

Concerning the canal between Spetses Island and the Argolida peninsula, seismic sections recorded in this area have shown that a seismic (C) horizon appears [10], which is possibly formed by Pliocene sediments due to its similarity to the Pliocene formations of the Argolida Gulf. In addition, in the mentioned seismic sections, a discontinuity appears between the Pliocene and the Quaternary sediments. This indicates that a part of this region uplifted during the Upper Pliocene and the erosion of the surficial geological formations was followed. In a second stage, during Lower Pleistocene, this region was again subsided and the Quaternary sediments were deposited. During Middle Pleistocene, normal faults prevail. Those recent faults have the same direction as those of the Upper Miocene age and thus might have been reactivated during this period. Or, the subsidence of the area between the Spetses island and the Argolida peninsula initiated during this period [11] [12].

As it is known, during Pleistocene, numerous successions of glacial or cold periods and temperate inter-glacial periods have been observed [13] until the last Upper Pleistocene glacial period. The glaciers increased their volume resulting to the lowering of the sea level by $110-120 \mathrm{~m}$ in relation to present sea-level. Spetses Island was connected with the opposite Argolida peninsula and remained exposed together to erosional processes. During this period the hydrographic network between Spetses Island and the Argolida peninsula, with northwest-southeast main direction has been formed [11] [12].

During Holocene, due to the sea level rise, a rather large part of the old land was flooded and Spetses Island isolated from the Argolida peninsula. Therefore, the main hydrographical network, which existed between the Argolida peninsula and Spetses Island as well as a large part of the main torrent branches at the south-eastern part of the island, are buried within the youngest seafloor sediments.

\section{Conclusions}

The island of Spetses, in the Argolikos gulf, of central Peloponnesus, is covered mainly by neogene and quaternary formations, deposited on Mesozoic limestones that are in a very limited extent. According to the micropaleontological determinations, the neogene sediments are of Upper Miocene age. This is of special interest for the evolutionary history of the broader area, as it is the first time that Miocene sediments have been recognized in the Peloponnesus, in which plio-pleistocene sediments have a very great extent. The sedimentary material, originated of limestones, radiolarites, flysch and also volcanic rocks, derived from the neighboring Argolida pe- 
ninsula, which seems to be uplifted and supplied material for the southern regions in the upper Miocene. Therefore, the region of Argolida together with the island of Spetses consisted of an independent paleogeographical unit from the rest of the Peloponnesus.

The island is affected by large NW-SE directed normal faults dipping to the NE or SW, as well as by ENEWSW to NE-SW oriented faults. The NW-SE faults were created during Upper Miocene and age responsible for the formation of the Argolikos Gulf.

The determined nannofossils indicated that the upper Miocene sediments were deposited in a warm coastal environment of normal salinity, which occasionally was connected go to the open sea. The climate was tropical-subtropical and the sedimentation depth was about 30 meters.

\section{Acknowledgements}

The author wishes to thank Mrs. E. Moraiti of the Institute of Geology and Mineral Exploration for the micropaleontological determinations.

\section{References}

[1] Bornovas, J. and Rondoyanni, Th. (1983) Geological Map of Greece, Scale 1:500.000. Institute of Geology and Mineral Exploration, Greece.

[2] Verginis, S. (1986) Beiträge zur Physischen Geographie des Nord-Peloponnes (Griechenland). Bulletin de la Société Géographique Héllénique, 4, 104, 334.

[3] Efstathiou, A., Tzanis, A., Chailas, S. and Stamatakis, M. (2012) Magmatic Activity at the NW Hellenic Volcanic Arc (Argolis Peninsula) and Its Relationship to Regional Tectonics: An Analysis Based on 3D Aeromagnetic Inversion and Other Geophysical and Geological Observations. International Conference "Volcanism of the Southern Aegean in the Frame of the Broader Mediterranean Area" (Volsam), Santorini, 10-12 October 2012, Abstract Volume.

[4] Mariolakos, I. (1976) Thoughts and Views on Certain Problems of Geological and Tectonic Structure of the Peloponnese. Annales Géologiques des Pays Helléniques, 27, 215-313.

[5] Gaitanakis, P. and Fotiadis, A. (1989) Les Unites Ophiolitiques de l'Argolide (Peloponnese, Grèce). Bulletin of the Geological Society of Greece, XXIII, 363-380.

[6] Bernoulli, D. and Jenkyns, H. (1974) Alpine, Mediterranean and Central Atlantic Mesozoic Facies in Relation to the Early Evolution of the Tethys. In: Doott Jr., R.H. and Shaver, P.H., Eds., Modern and Ancient Geosynclinal Sedimentation. Society of Economic Paleontologists and Mineralogists, SEPM Society for Sedimentary Geology, Special Publication 19, Tulsa, 129-160. http://dx.doi.org/10.2110/pec.74.19.0129

[7] Schröder, B. (1986) Das Postorogene Känozoikum in Griechenland/Ägäis. (von Jacobshagen, V. Geologie von Griechenland. Beiträge zur Regionalen Geologie der Erde. Berlin-Stuttgart, 209-240.

[8] Van Andel, Th., Perissoratis, C. and Rondoyanni, Th. (1993) Quaternary Tectonics of the Argolikos Gulf and Adjacent Basins, Greece. Journal of the Geological Society, 150, 529-539. http://dx.doi.org/10.1144/gsjgs.150.3.0529

[9] Gaitanakis, P. and Fotiadis, A. (1991) Geological Structure of SW Argolis (Peloponnesus, Greece). Bulletin of the Geological Society of Greece, 25, 319-338.

[10] Papanikolaou, D., Lykousis, V., Chronis, G. and Pavlakis, P. (1988) A Comparative Study of Neotectonic Basins across the Hellenic Arc: The Messiniakos, Argolikos, Saronikos and Southern Evoikos Gulfs. Basin Research, 1, 167176. http://dx.doi.org/10.1111/j.1365-2117.1988.tb00013.x

[11] Lykoudi, E. (1996) Geological and Geomorphological Observations on the Island of Spetses. M.Sc. Thesis, University of Athens, Athens.

[12] Lykoudi, E., Livaditis, G., Maroukian, H. and Bathrellos, G. (2004) Palaegeographic Evolution of the Drainage Networks of the Island of Spetses. Annales Géologiques des Pays Helléniques, I-XL, 89-98.

[13] West, R.G. (1977) Pleistocene Geology and Biology. 2nd Edition, Longman, London. 